\title{
Histopathology of gills, kidney and liver of a Neotropical fish caged in an urban stream
}

\author{
Marina M. P. Camargo and Cláudia B. R. Martinez
}

Histological changes in gills, kidney and liver were used to evaluate the health of the Neotropical fish species Prochilodus lineatus, subjected to in situ tests for 7 days in a disturbed urban stream and in a reference site, during winter and summer. In fish caged in the urban stream the most common lesions were epithelial lifting, hyperplasia and hypertrophy of the respiratory epithelium, lamellar fusion, and aneurysms in the gills; enlargement of the glomerulus, reduction of Bowman's space, occlusion of the tubular lumen, cloudy swelling and hyaline droplet degeneration in the kidneys; hepatocytes with hypertrophy, cytoplasmic and nuclear degeneration, melanomacrophage aggregates, bile stagnation and one case of focal necrosis in the liver. The lesions were comparatively most severe in the liver. Histopathology showed to be a very suitable biomarker for use in conjugation with the in situ test, because the seasonal variation did not interfere in the results and it was possible to differentiate the sites in the urban stream from the reference site.

Alterações histológicas nas brânquias, rim e fígado foram usadas para estudar a saúde da espécie neotropical de peixe Prochilodus lineatus, submetida a testes in situ por 7 dias em um ribeirão urbano contaminado e em um local de referência, durante o inverno e o verão. Nos peixes confinados no ribeirão urbano as lesões mais comumente encontradas foram elevação epitelial, hiperplasia e hipertrofia do epitélio respiratório, fusão lamelar e aneurismas, nas brânquias; aumento do glomérulo, redução do espaço de Bowman, oclusão da luz tubular, degeneração granular e degeneração hialina, no rim; hepatócitos hipertrofiados, degeneração citoplasmática e nuclear, agregados de melanomacrófagos, estagnação biliar e um caso de necrose focal, no fígado. As lesões foram comparativamente mais severas no fígado. A histopatologia mostrou ser um biomarcador muito apropriado quando usada conjuntamente com os testes in situ, porque parece não ter sofrido interferência da variação sazonal e permitiu diferenciar os locais estudados no ribeirão urbano do local de referência.

Key words: in situ tests, histopathological biomarkers, water quality.

\section{Introduction}

Urban streams are one of the ecosystems most hit by the contamination resulting from human activity (Paul \& Meyer, 2001). Agricultural, industrial and domestic effluents generally contain a wide variety of organic and inorganic pollutants, such as solvents, oils, heavy metals, pesticides, fertilizers and suspended solids (Pandey et al., 2003) and are, invariably, discharged into small rivers and streams, without proper treatment. Such contaminants change water quality and may cause many problems to fish, such as diseases and structural alterations (Chang et al., 1998).

Histopathological changes have been widely used as biomarkers in the evaluation of the health of fish exposed to contaminants, both in the laboratory (Wester \& Canton, 1991; Thophon et al., 2003) and field studies (Hinton et al., 1992; Schwaiger et al., 1997; Teh et al., 1997). One of the great advantages of using histopathological biomarkers in envi- ronmental monitoring is that this category of biomarkers allows examining specific target organs, including gills, kidney and liver, that are responsible for vital functions, such as respiration, excretion and the accumulation and biotransformation of xenobiotics in the fish (Gernhofer et al., 2001). Furthermore, the alterations found in these organs are normally easier to identify than functional ones (Fanta et al., 2003), and serve as warning signs of damage to animal health (Hinton \& Laurén, 1990).

In situ tests, in which healthy animals are taken to the field and exposed directly to the potentially contaminated environment, have frequently been used in environmental studies (Stien et al., 1998; Pacheco \& Santos, 1999; Parrot et al., 2000; Olsen et al., 2001; Pyle et al., 2001; Camargo \& Martinez, 2006). Coutinho \& Gokhale (2000) studied the histopathology of carp (Cyprinus carpio) and tilapia (Orechromis mossambicus) subjected to in situ tests at a sewage treatment plant in India. Giensy et al. (2003) made similar studies using goldfish

Laboratory of Animal Ecophysiology, Department of Physiological Sciences State University of Londrina (UEL), PR- 445, km 374, Caixa Postal 6001, 86051-990 Londrina, PR, Brazil. cbueno@uel.br 
(Carassius auratus) in the USA. Nevertheless, in Brazil in situ tests using histopathology of fish as biomarker of aquatic contamination have not yet been reported.

Cambé stream and its tributaries constitute the main hydrological basin of Londrina, a city of 500,000 inhabitants in Paraná state, Southern Brazil; the Cambé crosses the entire city and is widely used for recreational purposes, despite being seriously impaired by anthropogenic activities. It receives diffuse and point source discharges of industrial, domestic and agricultural wastes since its headwaters. Chemical water analyses of the upper reaches of Cambé stream showed large amounts of metals, mainly lead and aluminum (Yabe \& Oliveira, 1998). Winkaler et al. (2001) showed that feral fish from these upper areas present impaired health and Lemos et al. (2005) using comet assay demonstrated that such water induces DNA damage. More recently, Camargo \& Martinez (2006) showed that Prochilodus lineatus confined in these areas presented functional alterations in response to water contamination. The Neotropical fish species Prochilodus lineatus (Valenciennes, 1847) (= P. scrofa Steindachner, 1881), represents a well suited fish species to environmental monitoring as it is a detritivorous fish which is in contact with xenobiotics in water and in sediment and also has been shown to be sensitive to variations in water quality (Mazon \& Fernandes, 1999; Da Silva et al., 2004; Martinez et al., 2004; Almeida et al., 2005).

The aim of the present study was to evaluate the occurrence of histological alterations in gills, kidney and liver of the freshwater fish, Prochilodus lineatus, subjected to in situ tests along the upper reaches of Cambé stream, during winter and summer.

\section{Material and Methods}

Animals and in situ tests. Juveniles of $P$. lineatus (mean \pm SD: $28.6 \pm 0.8 \mathrm{~g}, \mathrm{~N}=53$ ) were obtained at the Hatchery Station of the State University of Londrina (EPUEL) The in situ tests were conducted during the winter (August and September) and the summer (February and March). The fish were kept in cages in the upper reaches of Cambé stream at three sites (A, $\mathrm{B}$ and $\mathrm{C}$ ), all located inside the city of Londrina-PR, and at one site on the Apertados stream, away from the urban area, as a reference site (Fig. 1). Sites A, B and C show strong anthropogenic influence, receiving domestic, agricultural and industrial effluents, conversely the Apertados stream presents a well preserved riparian forest and is relatively free of contaminants.

Water and sediment analysis. At each site, temperature, dissolved oxygen, conductivity and $\mathrm{pH}$ were determined immediately before installing the cages and after their removal. Data on rainfall in the region of Londrina were supplied by the Agronomic Institute of Paraná (IAPAR). Samples of water (3L) were collected at each site and were analyzed for organic matter, sulphate, phosphate, ammonia, nitrite and nitrate using procedures described in APHA (1998).
Histological procedures. At each site and in each season, six fishes were confined for seven days in cubic cages $(125 \mathrm{~L})$ held close to the sediment to allow fish feeding. Immediately after the one-week confinement, the fish were anesthetized with benzocaine $\left(0.1\right.$ g. $\left.\mathrm{L}^{-1}\right)$ and then sacrificed by cervical section. Pieces of gills, kidney and liver were excised, rinsed in physiological saline and fixed in aqueous Bouin's fluid for 6, 12 and 8 hours respectively. The tissues were dehydrated in an ethyl alcohol series of ascending concentrations, embedded in paraffin and sectioned at $5 \mathrm{~mm}$. The tissue sections were stained with haematoxilin-eosin (HE), 10 sections of each tissue from each fish were examined by light microscope. Some sections of liver were also stained with the PAS (Periodic Acid Schiff) method, for the detection of hepatocyte glycogen, as described by Mello \& Vidal (1980). Glycogen in the hepatocytes was quantified according to the following grades: $0=$ no glycogen; $1=$ little glycogen; $2=$ medium glycogen and $3=$ great amount of glycogen. After this analysis, a mean value for the glycogen content for each site was calculated for each season.

The presence of histological alterations for each organ was evaluated semi-quantitatively by the Degree of Tissue Change (DTC), which is based on the severity of the lesions. For DTC calculation (modified from Poleksic \& MitrovicTutundzic, 1994) the alterations in each organ were classified in progressive stages of damage to the tissue: stage I alterations, which do not alter the normal functioning of the tissue; stage II, which are more severe and impair the normal functioning of the tissue; and stage III, which are very severe and cause irreparable damage. A value of DTC was calculated for each animal by the formula: DTC $=(1 \mathrm{X} \mathrm{S} I)+(10 \mathrm{X} \mathrm{S} I I)+$ (100 X SIII) where $I, I I$ and $I I I$ correspond to the number of alterations of stages I, II and III, respectively. DTC values between 0 and 10 indicate normal functioning of the organ; values between 11 and 20 indicate slight damage to the organ; values between 21 and 50 indicate moderate changes in the organ; values between 50 and 100 indicate severe lesions and values above 100 indicate irreversible damage to the organ (Poleksic \& Mitrovic-Tutundzic, 1994).

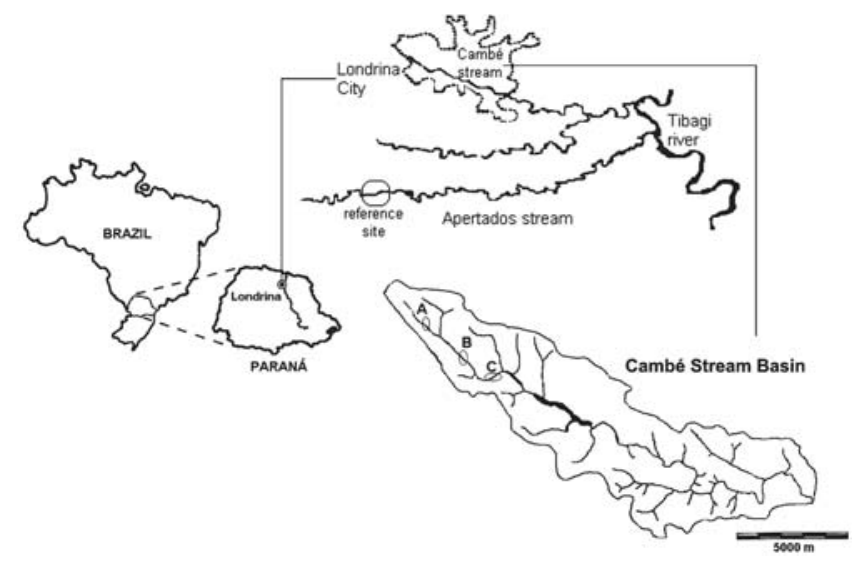

Fig. 1. Map showing the region of Londrina city (Paraná State), where the in situ tests were carried out at the reference site (Apertados stream), and the sites at Cambé stream (A, B and C). 
Statistical analysis. For each parameter, differences between sites on the Cambé stream and the reference site, in the same season, were tested for significance by one-way parametric ANOVA or the Kruskal-Wallis test, where appropriate, and the Student-Newman-Keuls (SNK) multiple-range test was used to identify the differences. The results obtained in the two seasons were compared by Student's $-t$ test. To all tests, significance was assigned for $P<0.05$.

\section{Results}

Quality of the water. The results of physical and chemical analysis of the water at the sampling sites are given in Table 1. During summer both temperature and rainfall were higher. The dissolved oxygen remained above $5.0 \mathrm{mg} \mathrm{O}_{2} \cdot \mathrm{L}^{-1}$ and $\mathrm{pH}$ close to 7.0 in both seasons for all sites. The values of conductivity were higher at the Cambé stream sites than at the reference site, being more than $100 \mu \mathrm{S} . \mathrm{cm}^{-1}$. Higher values of sulphate, phosphate, nitrite and nitrate were also observed at sites $\mathrm{B}$ and $\mathrm{C}$, in comparison to site $\mathrm{A}$.

Histopathology of the gill. The histological alterations found in the gills of the fish caged at the reference site and at the 3 sites at Cambé stream are detailed in Table 2. The commonest anomalies found were considered to be at stage I in severity; these include dilation of the marginal channel, hyperplasia of the epithelial cells and lifting of the lamellar epithelium (Fig. $2 b)$. There were some cases where the hyperplasia was more severe, resulting in the fusion of some secondary lamellae (Fig. 2c). Frequently, alterations such as blood congestion (Fig. 2c), hypertrophy of epithelial cells and lamellar disorganization (Fig. 2d) were also observed. Some examples of more severe lesions found in the gill (stage II) were lamellar aneurysms and hemorrhages with rupture of the lamellar epithelium (Fig. 2e). Very severe stage III lesions were not found in the gills of the fish studied.

The degree of tissue change (DTC) for the gills of fish caged at all sites vary from 3.6 to 13.2 with a mean value of 9.76, indicating normal functioning of the organ (Table 3). Significantly differences were detected only during the winter tests, when fish confined at sites $\mathrm{B}$ and $\mathrm{C}$ showed higher values of DTC than fish from reference site.

Histopathology of the kidney. The alterations found in the kidney are shown in Table 2 . The most important change found in the glomerulus of $P$. lineatus kidney was glomerular expansion, resulting in reduction of Bowman's space (Fig. 3b). In the tubules, the most frequent alterations were: cloudy swelling (Fig. 3c), occlusion of tubular lumen (Fig. 3c) and hyaline droplet degeneration (Fig. 3d). Less frequently, regenerating tubules (Fig. 3c) were seen. In the present study, very severe stage III lesions were not observed.

For all sites kidney DTC values ranged from 29.2 to 46.6, with a mean value of 39.84 , indicating moderate changes in the organ (Table 3 ). Seasonal variation was not detected. In the winter tests, none of the sites in the Cambé stream showed DTC significantly different from the reference site. However, during the summer tests, fish confined at sites $\mathrm{A}, \mathrm{B}$ and $\mathrm{C}$ showed DTC values significantly higher than those of the reference site.

Histopathology of the liver. The main alterations found in the liver (Table 2) were: irregular-shaped nuclei, nuclear hypertrophy, nuclear vacuolation and the presence of eosinophilic

Table 1. Average data of physical - chemical parameters of water from study sites at the beginning and the end of the caging period. Values are mean \pm S.E., excepting rainfall values, which correspond to the sum of the 3 days before and the 7 days caging period. $\mathrm{NM}=$ not measured.

\begin{tabular}{|c|c|c|c|c|c|}
\hline \multirow{2}{*}{ Parameter } & \multirow{2}{*}{ Season } & \multicolumn{4}{|c|}{ Sites } \\
\hline & & Reference & Site A & Site B & Site C \\
\hline \multirow{2}{*}{$\begin{array}{c}\text { D.O. } \\
\left(\mathrm{mgO}_{2} \cdot \mathrm{L}^{-1}\right)\end{array}$} & Winter & $9.1 \pm 1.77$ & $5.1 \pm 0.56$ & $7.6 \pm 0.28$ & $7.0 \pm 0.49$ \\
\hline & Summer & $7.8 \pm 1.34$ & $5.5 \pm 0.07$ & $7.7 \pm 1.2$ & $7.0 \pm 0$ \\
\hline \multirow{2}{*}{$\begin{array}{c}\text { Temperature } \\
\left({ }^{\circ} \mathrm{C}\right)\end{array}$} & Winter & $17.7 \pm 0.07$ & $22.1 \pm 0.35$ & $20.6 \pm 1.13$ & $17.4 \pm 2.34$ \\
\hline & Summer & $21.4 \pm 0.56$ & $26.0 \pm 0.28$ & $22.9 \pm 0.07$ & $24.0 \pm 0.07$ \\
\hline \multirow{2}{*}{$\mathrm{pH}$} & Winter & $7.6 \pm 0.35$ & $7.1 \pm 0.07$ & $7.3 \pm 0.07$ & $7.5 \pm 0.14$ \\
\hline & Summer & $7.6 \pm 0.07$ & $7.0 \pm 0.07$ & $7.2 \pm 0.07$ & $6.9 \pm 0.63$ \\
\hline \multirow{2}{*}{$\begin{array}{l}\text { Conductivity } \\
\left(\mu \mathrm{s} . \mathrm{cm}^{-1}\right)\end{array}$} & Winter & $65.0 \pm 10$ & $99.0 \pm 4.04$ & $115.5 \pm 0.49$ & $223.5 \pm 47.7$ \\
\hline & Summer & $83.0 \pm 0$ & $104.5 \pm 4.5$ & $138.5 \pm 0.49$ & $244.5 \pm 0.49$ \\
\hline \multirow{2}{*}{ Org. matter (mg.L $\left.{ }^{-1}\right)$} & Winter & \multirow{2}{*}{ NM } & $49.12 \pm 0$ & $30.32 \pm 13.67$ & $33.56 \pm 29.9$ \\
\hline & Summer & & $81.52 \pm 32.33$ & $71.57 \pm 23.70$ & $68.80 \pm 56.9$ \\
\hline \multirow{2}{*}{$\begin{array}{l}\text { Sulfate } \\
\left(\mathrm{mg} . \mathrm{L}^{-1}\right)\end{array}$} & Winter & \multirow{2}{*}{$\mathrm{NM}$} & $0.35 \pm 0.22$ & $4.99 \pm 4.41$ & $3.91 \pm 3.63$ \\
\hline & Summer & & $6.46 \pm 3.85$ & $8.93 \pm 1.71$ & $5.90 \pm 2.53$ \\
\hline \multirow{2}{*}{$\begin{array}{l}\text { Phosphate } \\
\left(\mathrm{mg}^{\left.-L^{-1}\right)}\right.\end{array}$} & Winter & \multirow{2}{*}{ NM } & $0.78 \pm 0.69$ & $4.05 \pm 3.29$ & $2.64 \pm 2.16$ \\
\hline & Summer & & $0.21 \pm 0.04$ & $0.34 \pm 0.06$ & $0.16 \pm 0.06$ \\
\hline \multirow{2}{*}{$\begin{array}{l}\text { Amônia } \\
\left(\mathrm{mg} \cdot \mathrm{L}^{-1}\right)\end{array}$} & Winter & \multirow{2}{*}{ NM } & $0.05 \pm 0.04$ & 0 & 0 \\
\hline & Summer & & $0.87 \pm 0.86$ & 0 & 0 \\
\hline \multirow{2}{*}{$\begin{array}{l}\text { Nitrite } \\
\left(\mathrm{mg} . \mathrm{L}^{-1}\right)\end{array}$} & Winter & \multirow{2}{*}{$\mathrm{NM}$} & $2.26 \pm 0.76$ & $9.09 \pm 0.01$ & $2.96 \pm 1.74$ \\
\hline & Summer & & $5.37 \pm 3.82$ & $2.0 \pm 0.84$ & $4.06 \pm 0.34$ \\
\hline \multirow{2}{*}{$\begin{array}{l}\text { Nitrate } \\
\left(\mathrm{mg} . \mathrm{L}^{-1}\right)\end{array}$} & Winter & \multirow{2}{*}{$\mathrm{NM}$} & $0.16 \pm 0.04$ & $0.87 \pm 0.28$ & $0.61 \pm 0.09$ \\
\hline & Summer & & $0.97 \pm 0.6$ & $1.11 \pm 0.48$ & $0.84 \pm 0.73$ \\
\hline \multirow{2}{*}{$\begin{array}{l}\text { Rainfall } \\
(\mathrm{mm})\end{array}$} & Winter & 0 & 17.2 & 12.4 & 22.0 \\
\hline & Summer & 27.6 & 21.2 & 17.0 & 33.1 \\
\hline
\end{tabular}


granules in the cytoplasm (Fig. 4b). Bile stagnation (Fig. 4c) was identified as brownish-yellow granules in the cytoplasm. Cytoplasmic and nuclear degeneration (Fig. 4d) was also very common; melanomacrophages (Fig. 4e) were identified as rounded aggregates of cells containing dark-yellowish granules of various sizes, normally close to the vessels. The majority of the alterations found in the liver of the caged animals belonged to stages I and II, i.e. the tissue was slightly to moderately damaged, and recuperation was still possible, if the water quality improved. Only one stage III lesion was found (focal necrosis, Fig. 4f) at site A, during the summer. This alteration is very severe and the damage caused to the tissue is irreversible.

The mean DTC for liver was 52.34 (values ranged from 35.3 to 174), indicating that in most cases, the hepatic lesions causes moderate to severe damage to the tissue (Table 3). The DTC values were significantly higher in the fish caged at all sites on the Cambé stream, during the winter, than at the reference site. There was seasonal variation at sites $\mathrm{B}$ and $\mathrm{C}$, the fish during the winter show more severe damage than in the summer. The high standard error value for site $\mathrm{A}$ in the summer was a consequence of the focal necrosis found in one fish at that site. This raised the DTC value significantly $(\mathrm{DTC}=174)$ in comparison with the other sites.


Fig. 2. Photomicrographs of the gill of $P$. lineatus caged in Cambé stream. a) normal aspect of the gill, showing the filament (gray arrow), the lamellae (L), the water channel $(*)$, a pillar cell (black arrow) and an epithelial cell (arrowhead); b) lamellae with the marginal channel dilated (black arrow), hyperplasia of the epithelial cells (white arrow) and epithelial lifting (arrowheads); c) fusion of 3 lamellae (white arrow) and blood congestion (arrowhead); d) lamellar disorganization (arrowheads), partial fusion of some lamellae (white arrow) and hypertrophy of the lamellar epithelium (black arrow); e) lamellar aneurysm (white arrow) and epithelium rupture with hemorrhage $\left(^{*}\right)$. Scale bar $20 \mathrm{~mm}$, H.E. 
Table 2. Histopathological changes in the gills, kidney and liver of $P$. lineatus caged at three sites along the upper reaches of Cambé stream and at the reference site indicating their respective stages of damage to the tissue. Stage I: do not alter the normal functioning of the tissue; Stage II: more severe and impair the normal functioning of the tissue; Stage III: very severe and cause irreparable damage.

\begin{tabular}{|c|c|c|c|}
\hline Stage & Gills & Kidney & Liver \\
\hline I & $\begin{array}{l}\text { Hyperplasia of the gill epithelium } \\
\text { Hypertrophy of the gill epithelium } \\
\text { Blood congestion } \\
\text { Dilation of the marginal channel } \\
\text { Epithelial lifting of lamellae } \\
\text { Lamellar fusion } \\
\text { Lamellar disorganization }\end{array}$ & $\begin{array}{c}\text { CORPUSCLE } \\
\text { Dilation of glomerular capillaries } \\
\text { Glomerular enlargement } \\
\text { TUBULES } \\
\text { Nuclear hypertrophy } \\
\text { Cellular hypertrophy } \\
\text { Cytoplasmic vacuolation } \\
\text { Cloudy swelling } \\
\text { Dilation of the tubular lumen } \\
\text { Tubular regeneration } \\
\text { Melanomacrophages aggregates }\end{array}$ & $\begin{array}{c}\text { Nuclear hypertrophy } \\
\text { Irregular shaped nucleus } \\
\text { Nucleus in a lateral position } \\
\text { Cellular hypertrophy } \\
\text { Cytoplasmic vacuolation } \\
\text { Cellular atrophy } \\
\text { Irregular shaped cells } \\
\text { Eosinophilic granules in cytoplasm } \\
\text { Melanomacrophages aggregates }\end{array}$ \\
\hline II & $\begin{array}{l}\text { Lamellar aneurysm } \\
\text { Rupture of epithelial cells with } \\
\text { hemorrhages }\end{array}$ & $\begin{array}{l}\text { Bowman's space decrease } \\
\text { Blood in Bowman's space } \\
\text { Hyaline droplets degeneration } \\
\text { Tubular degeneration Decrease of the } \\
\text { tubular lumen caliber }\end{array}$ & $\begin{array}{c}\text { Nuclear vacuolation } \\
\text { Cytoplasmic degeneration } \\
\text { Cellular rupture } \\
\text { Blood congestion } \\
\text { Nuclear degeneration } \\
\text { Picnotic nucleus } \\
\text { Bile stagnation } \\
\end{array}$ \\
\hline III & Not found & Not found & Focal necrosis \\
\hline
\end{tabular}
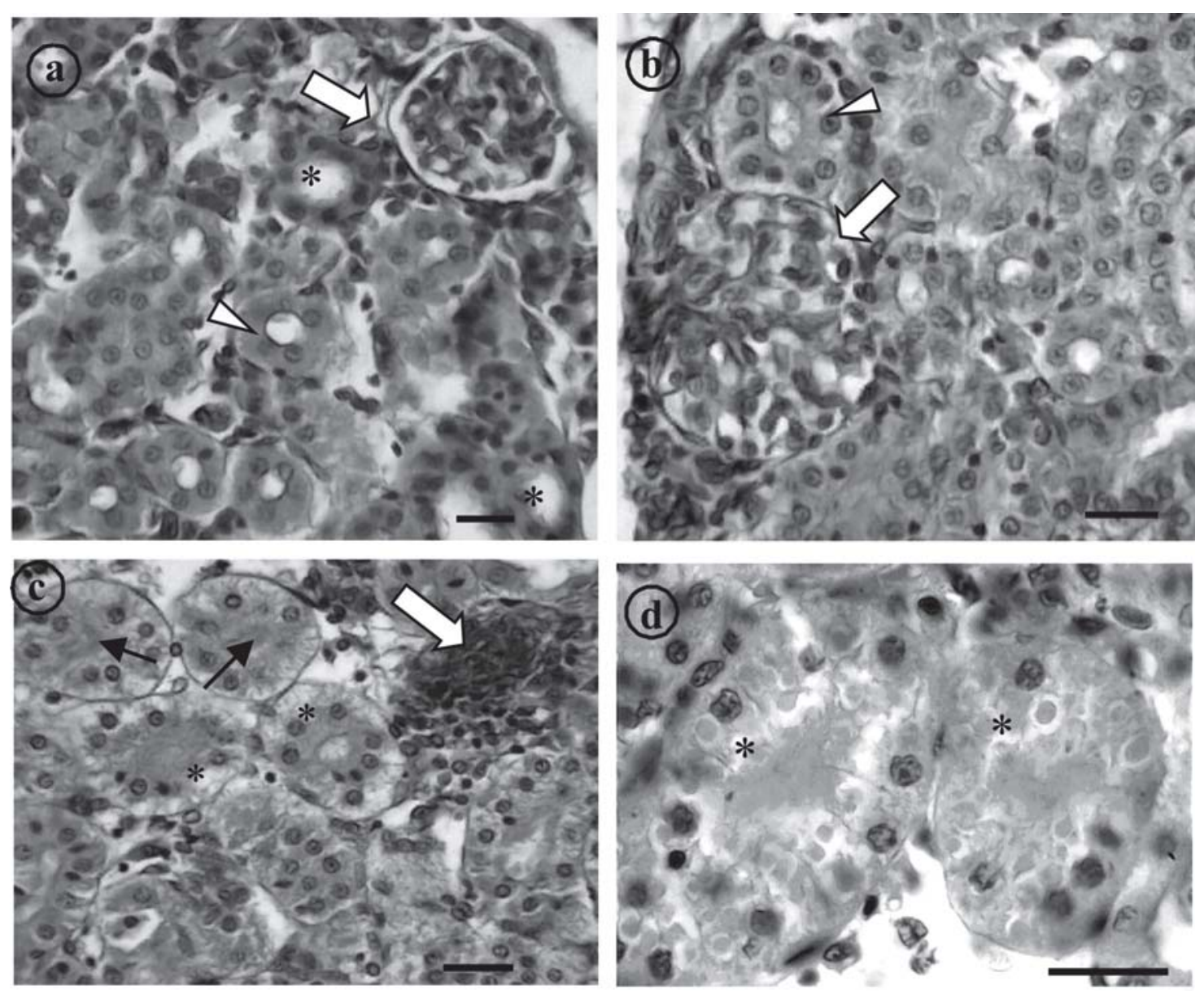

Fig. 3. Photomicrographs of the kidney of $P$. lineatus caged in Cambé stream. a) normal renal corpuscle showing the glomerulus and the Bowman's space well defined (arrow), proximal tubules (*), distal tubules (arrowheads); b) glomerular expansion and absence of the Bowman's space (arrow) and tubule cells with hypertrophied nucleus (arrowheads); c) tubule starting the regeneration process (white arrow), occlusion of the tubular lumen (black arrows) and cloudy swelling degeneration $\left({ }^{*}\right) ; \mathrm{d}$ ) detail of 2 tubules with hyaline droplets degeneration (*). Scale bar $10 \mathrm{~mm}$, H.E. 
The amount of glycogen tended to decrease in the hepatocytes of the fish during the summer. This reduction was significant only in the fish at site B (Table 4). However, there was no statistical difference between the fish kept at sites A, $\mathrm{B}$ and $\mathrm{C}$ and the reference one.

During winter, the area of the nuclei of the hepatocyte in the fish from sites A and B was higher than those from the reference site (Table 4). During summer, however, the nuclear area was higher in the fish at site B only. The diameter of the nuclei of the hepatocytes in the fish in both seasons from site B showed significantly higher values compared to those from the reference site (Table 4).

\section{Discussion}

The physical and chemical analyses are essential to evaluate water quality, as they provide important data about the variations caused by the different seasons during the year. In tropical climates, the commonest changes are daily, and the changes between summer and winter are the most evident seasonal ones (Esteves, 1988). In the present study, as expected in tropical climates, higher temperatures and rainfall values, on average, were recorded at the sampling sites during the summer months than in winter months. None of the tested water samples showed dissolved oxygen (D.O.) below $4 \mathrm{mgO}_{2} \cdot \mathrm{L}^{-1}$, considered critical by Esteves (1988). The highest values of conductivity were found at site $C$, both in summer and winter. Conductivity above $100 \mu \mathrm{S} . \mathrm{cm}^{-1}$ has been associated with impaired water bodies (Cetesb, 2001) and may re-

Table 3. Degree of Tissue Change for the gills, kidney and liver of P. lineatus caged at the 3 sites at Cambé stream (A, B and $C$ ) and at the reference site, in the winter and the summer. Results are mean \pm SE. *indicates statistical difference in relation to the reference site; $* *$ indicates statistical difference in relation to winter results $(P<0.05)$.

\begin{tabular}{ccccc}
\hline \multirow{2}{*}{$\begin{array}{c}\text { Caging } \\
\text { Sites }\end{array}$} & \multirow{2}{*}{ Season } & \multicolumn{3}{c}{ Degree of Tissue Change } \\
\cline { 3 - 5 } Reference & Summer & $7.5 \pm 2.2$ & $29.2 \pm 2.2$ & $35.3 \pm 2.9$ \\
& Winter & $3.6 \pm 0.5$ & $31.3 \pm 2.9$ & $38.8 \pm 0.5$ \\
\hline \multirow{2}{*}{ Site A } & Summer & $10.5 \pm 1.9$ & $40.8 \pm 4.6^{*}$ & $66.5 \pm 22.0$ \\
& Winter & $8.0 \pm 1.8$ & $42.8 \pm 2.0$ & $60.0 \pm 3.9^{*}$ \\
\hline \multirow{2}{*}{ Site B } & Summer & $9.2 \pm 2.5$ & $44.2 \pm 2.4^{*}$ & $47.0 \pm 5.0^{* *}$ \\
& Winter & $12.8 \pm 1.6^{*}$ & $44.0 \pm 4.4$ & $60.0 \pm 3.7^{*}$ \\
\hline \multirow{2}{*}{ Site C } & Summer & $13.2 \pm 2.3$ & $46.6 \pm 4.1^{*}$ & $46.7 \pm 3.9^{* *}$ \\
& Winter & $13.2 \pm 3.6^{*}$ & $39.8 \pm 4.9$ & $64.4 \pm 3.7^{*}$ \\
\hline
\end{tabular}

flect a decrease in water quality (Olsen et al., 2001). At site C an increased loading of nutrients was also detected, as indicated by concentrations of phosphates, nitrite and nitrate. This increase indicates the discharge of effluents into the stream, near site $\mathrm{C}$.

The gills, which participate in many important functions in fish, such as respiration, osmoregulation and excretion, remain in close contact with the external environment, and particularly sensitive to changes in the quality of the water, are considered the primary target of the contaminants (Poleksic \& Mitrovic-Tutundzic, 1994; Mazon et al., 2002; Fernandes \& Mazon, 2003). Alterations like epithelial lifting, hyperplasia and hypertrophy of the epithelial cells, besides partial fusion of some secondary lamellae are examples of defense mechanisms, since, in general, these result in the increase of the distance between the external environment and the blood and thus serve as a barrier to the entrance of contaminants (Mallatt, 1985; Hinton \& Laurén, 1990; Poleksic \& Mitrovic-Tutundzic, 1994; Fernandes \& Mazon, 2003). These alterations were most common found in the gills of fish caged in the Cambé stream. Coutinho \& Gokhale (2000) found epithelial lifting in the gills of carps (Cyprinus carpio) and tilapias (Oreochromis mossambicus) exposed to the effluents of a wastewater treatment plant. Engelhardt et al. (1981) observed epithelial lifting and lamellar fusion in rainbow trouts (Oncorhynchus mykiss) exposed to petroleum residues. Similar alterations in the gills have also been reported in the fishes exposed to metals (Oliveira Ribeiro et al., 2000; Cerqueira \& Fernandes, 2002; Martinez et al, 2004) and organic contaminants (Rosety-Rodríguez et al., 2002; Fanta et al., 2003). According to Mallat (1985) such alterations are non-specific and may be induced by different types of contaminant (Mallatt, 1985). As a consequence of the increased distance between water and blood due to epithelial lifting, the oxygen uptake is impaired. However, fishes have the capacity to increase their ventilation rate, to compensate low oxygen uptake (Fernandes \& Mazon, 2003).

Most part of the gill lesions caused by sublethal exposures affects lamellar epithelium (Hinton \& Laurén, 1990); however, some alterations in blood vessels may also occur, when fishes suffer a more severe type of stress. In this case, damaged pillar cells can result in an increased blood flow inside the lamellae, causing dilation of the marginal channel, blood congestion or even an aneurysm (Takashima \& Hibiya, 1995; Rosety-Rodríguez et al., 2002). The formation of an an-

Table 4. Hepatic glycogen content and hepatocytes nuclear area and diameter of $P$. lineatus confined at reference site and at the 3 sites at Cambé stream (A, B and C), during winter and summer. Values indicate mean \pm S.E. In the winter $\mathrm{n}=6$ for the Reference, Site $\mathrm{A}$ and Site $\mathrm{B}$, and $\mathrm{n}=5$ for site $\mathrm{C}$. In the summer $\mathrm{n}=6$ for Reference and Site $\mathrm{A}, \mathrm{n}=4$ for Site $\mathrm{B}$ and $\mathrm{n}=5$ for site $\mathrm{C}$. * indicates value significantly different from the reference site, and \# indicates value significantly different from the winter result $(P<0.05)$.

\begin{tabular}{|c|c|c|c|c|c|c|}
\hline \multirow{2}{*}{ Site } & \multicolumn{2}{|c|}{ Glycogen } & \multicolumn{2}{|c|}{ Area $\left(\mu m^{2}\right)$} & \multicolumn{2}{|c|}{ Diameter $(\mu \mathrm{m})$} \\
\hline & Winter & Summer & Winter & Summer & Winter & Summer \\
\hline Reference & $2.00 \pm 0.36$ & $1.50 \pm 0.22$ & $38.80 \pm 1.25$ & $37.62 \pm 0.83$ & $6.60 \pm 0.13$ & $6.99 \pm 0.09 \#$ \\
\hline Site A & $2.80 \pm 0.20$ & $2.16 \pm 0.30$ & $42.05 \pm 2.57$ & $36.38 \pm 1.37$ & $6.92 \pm 0.20$ & $6.75 \pm 0.12$ \\
\hline Site B & $2.66 \pm 0.21$ & $2.00 \pm 0.00 \#$ & $42.99 \pm 1.12$ & $46.11 \pm 1.31 *$ & $7.20 \pm 0.08 *$ & $7.85 \pm 0.19 * \#$ \\
\hline Site C & $2.60 \pm 0.24$ & $2.40 \pm 0.24$ & $38.97 \pm 1.11$ & $37.33 \pm 1.77$ & $7.02 \pm 0.13$ & $6.70 \pm 0.11$ \\
\hline
\end{tabular}



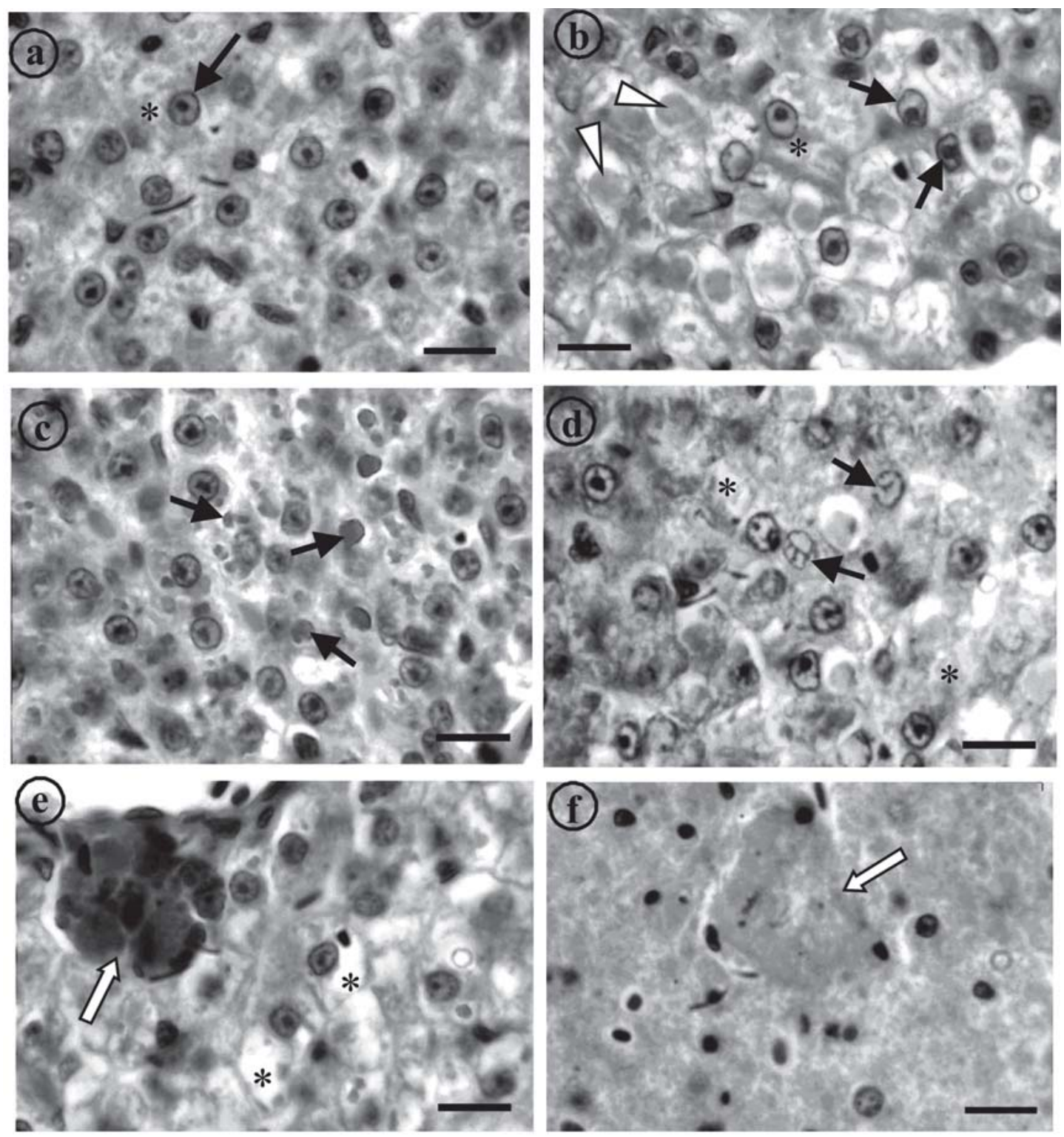

Fig. 4. Photomicrographs of the liver of $P$. lineatus caged in Cambé stream. a) normal hepatic tissue, showing hepatocytes with granular cytoplasm $(*)$ and central and round nucleus (arrow); b) hepatocytes with irregular shaped nucleus (black arrows), eosinophilic granules in the cytoplasm (arrowheads) and nuclear hypertrophy (*); c) bile stagnation (arrows); d) nuclear degeneration (arrows) and cytoplasmic degeneration $(*)$; e) melanomacrophages aggregate, close to a vessel (white arrow) and cytoplasmic vacuolation (*); f) hepatic tissue showing focal necrosis (white arrow). Scale bar $10 \mathrm{~mm}$, H.E.

eurysm is related to the rupture of the pillar cells (Heath, 1987; Martinez et al., 2004) due to a bigger flow of blood or even because of the direct effects of contaminants on these cells. This is a severe type of lesion, recovery from which is possible, but more difficult than the epithelial changes (Poleksic \& Mitrovic-Tutundzic, 1994). Several animals caged in the Cambé stream showed vascular alterations, the most frequent being dilation of the marginal channel and congestion. Some animals confined at sites $\mathrm{A}$ and $\mathrm{C}$ showed aneurysms which indicate the impaired condition of the water in these sites.

In the present study, one fish confined at site B in the winter showed rupture of the gill epithelium, which caused hemorrhage. Like aneurysm, this lesion can be interpreted as a reflection of the direct action of toxic agents on the tissue (Temmink, 1983).

Winkaler et al. (2001) found anomalies such as hyperplasia, hypertrophy, dilation of the marginal channel and aneurysms in another Neotropical fish, Astyanax altiparanae, collected in Cambé stream, which corroborates the hypothesis that the water of this stream is really contaminated and that exposure to this water causes structural damage to the fish gill.

The teleostean kidney is one of the first organs to be affected by contaminants in the water (Thophon et al., 2003). Most common alterations found in the kidney of fishes ex- 
posed to water contamination are tubule degeneration (cloudy swelling and hyaline droplets) and changes in the corpuscle, such as dilation of capillaries in the glomerulus and reduction of Bowman's space (Takashima \& Hibiya, 1995). Exposure to metals frequently causes alterations in the tubules and glomerulus, such as was described by Thophon et al. (2003) for the perch (Lates calcarifer) exposed to cadmium; Handy \& Penrice (1993) found swollen Bowman's capsule cells and melanomacrophages in the kidney of trout (Salmo trutta) and tilapia (Oreochromis mossambicus) exposed to mercuric chloride. Similar alterations were found in fishes exposed to organic contaminants (Veiga et al., 2002) and mixed environmental contaminants (Schwaiger et al., 1997; Pacheco \& Santos, 2002). These reports suggest that the histopathological changes in the kidney, like in gills, could not be considered specific to the stressors. In the present study, kidney of the fish often showed cloudy swelling in tubule cells. This alteration can be identified by the hypertrophy of the cells and the presence of small granules in the cytoplasm, which takes on the appearance of a net. This initial stage in the degeneration process can progress to hyaline degeneration, characterized by the presence of large eosinophilic granules inside the cells. These granules may be formed inside the cells or by the reabsorption of plasma proteins lost in the urine, indicating damage in the corpuscle (Hinton \& Laurén, 1990; Takashima \& Hibiya, 1995). In more severe cases, the degenerative process can lead to tissue necrosis (Takashima \& Hibiya, 1995). The presence of tubule degeneration, coupled with the absence of necrosis in the kidney in the present study indicates that the kidney suffered damage after exposure to the water of the Cambé stream, but the short period of confinement may have prevented the establishment of necrosis in this organ.

The development of new nephrons occurs only in the neonatal period in mammals, while, in fish this process continues throughout life, being more frequent in young and fast-growing fishes (Reimschuessel, 2001). Hinton \& Laurén (1990) and Cormier et al. (1995) have reported the increase in the frequency of new nephrons and regenerated tubules, during the process of the recovery of the damaged kidney in fish. Similar observations have also been made in the siluriform Ameiurus nebulosus and in cod (Microgadus tomcod) collected from contaminated streams (Cormier et al., 1995), and in goldfish (Carassius auratus), rainbow trout (Oncorhynchus mykiss), zebrafish (Brachidanio rerio) and tilapia (Oreochromis mossambicus) exposed to contaminants such as mercury, antibiotics and solvents, that are known to cause necrosis and vacuolization (Reimschuessel, 2001). In the fish confined in the Cambé stream, the new nephrons are relatively less. This may considered normal process of development of the kidney tissue and not due to the quality of the water, since only juvenile specimens were used in the in situ tests. It could be possible that the short period of exposure may have not been sufficient to start the regeneration process, because this phenomenon usually starts from 2 to 4 weeks after exposure to the stressor (Reimschuessel, 2001), and could even take 2 months to be completed (Gernhofer et al., 2001).
The organ most associated with the detoxification and biotransformation process is the liver, and due to its function, position and blood supply (Van der Oost et al., 2003) it is also one of the organs most affected by contaminants in the water (Rodrigues \& Fanta, 1998).

Anomalies such as irregular shaped hepatocytes, cytoplasmic vacuolation and nucleus in a lateral position, close to the cell membrane, were also described in the siluriform Corydoras paleatus contaminated by organophosphate pesticides (Fanta et al., 2003). Vacuoles in the cytoplasm of the hepatocytes can contain lipids and glycogen, which are related to the normal metabolic function of the liver. Depletion of the glycogen in the hepatocytes is usually found in stressed animals (Hinton \& Laurén, 1990; Wilhelm Filho et al., 2001), because the glycogen acts as a reserve of glucose to supply the higher energetic demand occurring in such situations (Panepucci et al., 2001). In the present study, no statistical difference was seen in the glycogen, between the animals confined in Cambé stream and at reference site. However, the tendency of the animals to show less glycogen in the summer may be related to the higher metabolic rate caused by the higher temperatures.

Pacheco \& Santos (2002) described increased vacuolisation of the hepatocytes as a signal of degenerative process that suggests metabolic damage, possibly related to exposure to contaminated water. Presence of mainly glycogen in the vacuoles of the hepatocytes shown by PAS method in the present study, however, suggests that, the vacuolisation need not be related to a degenerative process.

The liver parenchyma of the animals exposed to the water of the Cambé stream showed signs of degeneration (cytoplasmic and nuclear degeneration, and nuclear vacuolation) besides the focal necrosis that was found in one fish confined at site A. These alterations are more severe and have been associated with the exposure of the fishes to contamination by metals, such as copper (Paris-Palacios et al., 2000) and mercury (Oliveira Ribeiro et al., 1996), and by polychlorinated biphenyls (PCBs) (Chang et al., 1998).

The present study shows that the histopathological changes in the liver cause metabolic problems as well. Evidence for this is the bile stagnation in liver of most fish studied. This lesion, characterized by the remains of the bile in the form of brownish-yellow granules in the cytoplasm of the hepatocytes (Pacheco \& Santos, 2002), indicates that the bile is not being released from the liver. This accumulation of bile indicates possible damage to the hepatic metabolism (Fanta et al., 2003).

An increase in the density of the melanomacrophage aggregates, as observed in the liver of $P$. lineatus in this study, is generally related to important hepatic lesions (Pacheco \& Santos, 2002), such as degenerative and necrotic processes. This was related, in Pleuronectes americanus, to contamination with PAHs (polycyclic aromatic hydrocarbons) and pesticides in urban areas on the USA coast (Chang et al., 1998). The function of the melanomacrophages in the liver of fishes remains uncertain, but some studies have suggested that it is related to destruction, detoxification or recycling of endog- 
enous and exogenous compounds (Haaparanta et al., 1996).

The presence of bile stagnation and melanomacrophages in great quantity in the livers of caged $P$. lineatus is strong evidence that these organs suffered structural and metabolic damage due to exposure to the Cambé stream water, reinforcing the idea that this environment is really impaired.

Among the sites studied in the Cambé stream, site $\mathrm{C}$ was considered the most impaired, because of the high DTC values found there for all three organs examined. This is probably due to the location of this site, downstream of all the other sites, and also its lentic characteristics, that make the accumulation of contaminants an easier process.

The histological changes observed in the gills, kidney and liver of the $P$. lineatus in the present study indicate that the fish were responding to the direct effects of the contaminants as much as to the secondary effects caused by stress. The analysis of the seasonal variation in the histological parameters leads to the conclusion that the changes observed in the three organs were not apparently related to the seasons, and neither were the distribution or the severity of the lesions. Such information confirms that histopathological alterations are good biomarkers for field assessment, in particular in tropical areas that are naturally subject to a multiplicity of environmental variations. It must be emphasized that histopathology is able to evaluate the early effects and the responses to acute exposure to chemical stressors.

In conclusion the present study showed that histopathology is a useful biomarker for environmental contamination, since it discriminated between reference and test sites in the Cambé stream, and did not suffer significant interference from seasonal variation. The liver showed to be the organ most affected by the type of stressors to which the fish were subjected. The neotropical fish species, P. lineatus, was shown to be appropriate for in situ tests and environmental monitoring.

\section{Acknowledgements}

To the Hatchery Station of the State University of Londrina (EPUEL), for the supply of the fish, to IAPAR, for the rainfall data, to CAPES, for the Master's scholarship awarded to M. M. P. Camargo, to Dr. Paulo César Meletti, for helping with the analysis of the water and sediment, and to the Postgraduate Program of Biological Sciences/CCB/UEL.

\section{Literature Cited}

Almeida, J. S., P. C. Meletti \& C. B. R. Martinez. 2005. Acute effects of sediments taken from an urban stream on physiological and biochemical parameters of the neotropical fish Prochilodus lineatus. Comparative Biochemistry and Physiology (C), 140: 356-363.

APHA, 1998. In: Clesceri, L. S., A. E. Greenberg \& A. D. Eaton (Eds.). Standard methods for the examination of water and wastewater, 20th edition. Washington, American Public Health Association.

Camargo, M. M. P. \& C. B. R. Martinez. 2006. Biochemical and physiological biomarkers in Prochilodus lineatus submitted to in situ tests in an urban stream in southern Brazil. Environmental Toxicology and Pharmacology, 21: 61-69.

Cerqueira, C. C. C. \& M. N. Fernandes. 2002. Gill tissue recovery after cooper exposure and blood parameter responses in the tropical fish Prochilodus scrofa. Ecotoxicology and Environmental Safety, 52: 83-91.

CETESB (Companhia de Tecnologia de Saneamento Ambiental). 2001. Relatório de qualidade das águas interiores do estado de São Paulo. São Paulo, CETESB, 352p.

Chang, S., V. S. Zdanowicz \& R. A. Murchelano. 1998. Associations between liver lesions in winter flounder (Pleuronectes americanus) and sediment chemical contaminants from north-east United States estuaries. Journal of Marine Sciences, 55: 954-969.

Cormier, S. M., T. W. Neiheisel, P. Wersing, R. N. Racine \& R. Reimschuessel. 1995. New nephron development in fish from polluted waters: a possible biomarker. Ecotoxicology, 4: 157-168.

Coutinho, C. \& K. S. Gokhale. 2000. Selected oxidative enzymes and histopathological changes in the gills of Cyprinus carpio and Oreochromis mossambicus cultured in secondary sewage effluent. Water Research, 34: 2997-3004.

Engelhardt, F. R., M. P. Wong \& M. E. Duey. 1981. Hydromineral balance and gill morphology in rainbow trout Salmo gairdneri, acclimated to fresh and sea water as affected by petroleum exposure. Aquatic Toxicology, 1: 175-186.

Esteves, F. A.1988. Fundamentos de limnologia. Rio de Janeiro, Interciência/FINEP.

Fanta, E., F. S. Rios, S. Romão, A. C. C. Vianna \& S. Freiberger. 2003. Histopathology of the fish Corydoras paleatus contaminated with sublethal levels of organophosphorus in water and food. Ecotoxicology and Environmental Safety, 54: 119-130.

Fernandes, M. N. \& A. F. Mazon. 2003. Environmental pollution and fish gill morphology. In: Val, A. L. \& B. G. Kapoor (Eds.). Fish adaptations. Enfield, Science Publishers, 203-231.

Gernhofer, M., M. Pawet, M. Schramm, E. Müller \& R. Triebskorn. 2001. Ultrastructural biomarkers as tools to characterize the health status of fish in contaminated streams. Journal of Aquatic Ecossystem, Stress and Recovery, 8: 241-260.

Giensy, J. P., E. M. Snyder, K. M. Nichols, S. A. Snyder, S. A. Villalobos, P. D. Jones \& S. D. Fitzgerald. 2003. Examination of reproductive endpoints in goldfish (Carassius aurata) exposed in situ to municipal sewage treatment plant effluent discharges in Michigan, USA. Environmental Toxicology and Chemistry, 22: 2416-2431.

Haaparanta, A., E. T. Valtonen, R. Hoffaman \& J. Colmes. 1996. Do macrophages centres in freshwater fishes reflect the differences in water quality? Aquatic Toxicology, 34: 253-272.

Handy, R. D. \& W. S. Penrice. 1993. The influence of high oral doses of mercuric chloride on organ toxicant concentrations and histopathology in rainbow trout, Oncorhynchus mykiss. Comparative Biochemistry and Physiology (C), 106: 717-724.

Heath, A. G. 1987. Water pollution and fish physiology. Boca Raton, CRC Press.

Hinton, D. E., P. C. Baumann, G. R. Gardner, W. E. Hawkins, J. D. Hendricks, R. A. Murchelano \& M. S. Okihiro. 1992. Histopathologic biomarkers. In: Hugget, R., R. Kimerle, P. Mehrle \& H. Bergman (Eds.). Biomarkers - biochemical, physiological and histological markers of anthropogenic stress. Boca Raton, Lewis Publishers, pp.155-195.

Hinton, D. E. \& D. J. Laurén. 1990. Liver structural alterations accompanying chronic toxicity in fishes: potentioal biomarkers of exposure. Pp. 51-65. In: McCarthy, J.F. \& L.R. Shugart (Eds.). Biomarkers of Environmental Contamination. Boca Raton, Lewis Publishers. 
Lemos, N. G., A. L. Dias, A. T. Silva-Souza \& M. S. Mantovani. 2005. Evaluation of environmental waters using the comet assay in Tilapia rendalli. Environmental Toxicology and Pharmacology, 19: 197-201.

Mallatt, J. 1985. Fish gill structural changes induced by toxicants and other irritants: a statistical review. Canadian Journal of Fish and Aquatic Sciences, 42: 630-648.

Martinez, C. B. R., M. Y. Nagae, C. T. B. V. Zaia \& D. A. M. Zaia. 2004. Morphological and physiological acute effects of lead in the neotropical fish Prochilodus lineatus. Brazilian Journal of Biology, 64 (4): 797-807.

Mazon, A. \& M. N. Fernandes. 1999. Toxicity and differential tissue accumulation of copper in the tropical freshwater fish $P$. scrofa (Prochilodontidae). Bulletin of Environmental Contamination and Toxicology, 63: 794-804.

Mazon, A. F., G. H. D. Pinheiro \& M. N. Fernandes. 2002. Hematological and physiological changes induced by short-term exposure to copper in the freshwater fish, Prochilodus scrofa. Brazilian Journal of Biology, 62 (4A): 621-631.

Mello, M. L. S. \& B. C. Vidal. 1980. Práticas de biologia celular. São Paulo, Edgar Blücher.

Oliveira Ribeiro, C. A., E. Fanta, N. M. Turcatti, R. J. Cardoso \& C. S. Carvalho. 1996. Lethal effects of inorganic mercury on cells and tissues of Trichomycterus brasiliensis (Pisces; Siluroidei). Biocell, 20: 171-178.

Oliveira Ribeiro, C. A., E. Pelletier, W. C. Pfeiffer \& C. Rouleau. 2000. Comparative uptake, bioaccumulation, and gill damages of inorganic mercury in tropical and nordic freshwater fish. Environmental Research, 83: 286-292.

Olsen, T., L. Ellerbeck, T. Fisher, A.Callaghan \& M. Crane. 2001. Variability in acetylcholinesterase and glutathione S-transferase activities in Chironomus riparus meigen deployed in situ at uncontaminated field sites. Environmental Toxicology and Chemistry, 20: 1725-1732.

Pacheco, M. \& M. A. Santos. 1999. Biochemical and genotoxic responses of adult eel (Anguilla anguilla $\mathrm{L}$.) to resin acids and pulp mill effluent: laboratory and field experiments. Ecotoxicology and Environmental Safety, 42: 81-93.

Pacheco, M. \& M. A. Santos. 2002. Biotransformation, genotoxic and histopathological effects of environmental contaminants in European eel (Anguilla anguilla L.). Ecotoxicology and Environmental Safety, 53: 331-347.

Pandey, S., S. Parvez, I. Sayeed, R. Haque, B. Bin-Hafeez \& S. Raisuddin. 2003. Biomarkers of oxidative stress: a comparative study of river Yamuna fish Wallago att (B1. \& Schn.). Science of the total environment, 309: 105-115.

Panepucci, R. A., L. Panepucci, M. N. Fernandes, J. R. Sanchez \& F. T Rantin. 2001. The effect of hypoxia and recuperation on carbohydrate metabolism in pacu (Piaractus mesopotamicus). Brazilian Journal of Biology, 61: 547-554.

Paris-Palacios, S., S. Biagianti-Risbourg \& G. Vernet. 2000. Biochemical and (ultra)structural hepatic perturbations of Brachyodanio rerio (Teleostei, Cyprinidae) exposed to two sublethal concentrations of cooper sulfate. Aquatic Toxicology, 50: 109-124.

Parrot, J. L., M. R. Van den Heuvel, L. Mark-Hewitt, M. A. Baker \& K. R. Munkittrick. 2000. Isolation of MFO inducers from tissues of white suckers caged in bleached kraft mill effluent. Chemosphere, 41: 1083-1089.

Paul, M. J. \& J. L. Meyer. 2001. Streams in the urban landscape. Annual Review of Ecology and Systematic, 32: 333-65.

Poleksic, V. \& V. Mitrovic-Tutundzic. 1994. Fish gills as a monitor of sublethal and chronic effects of pollution. Pp. 339-352. In: Müller, R. \& R. Lloyd (Eds.). Sublethal and Chronic effects of pollutants on freshwater fish. Oxford, Fishing News Books.
Pyle, G. G., S. M. Swanson \& D. M. Lehmkuhl. 2001. Toxicity of uranium mine-receiving waters to caged fathead minnows, Pimephales promelas. Ecotoxicology and Environmental Safety, 48: 202-214.

Reimschuessel, R. 2001. A fish model of renal regeneration and development. Ilar Journal, 42: 285-291.

Rodrigues, E. L. \& E. Fanta. 1998. Liver histopathology of the fish Brachydanio rerio after acute exposure to sublethal levels of the organophosphate Dimetoato 500. Revista Brasileira de Zoologia, 15: 441-450.

Rosety-Rodríguez, M., F. J. Ordoñez, M. Rosety, J. M. Rosety, A. Ribelles \& C. Carrasco. 2002. Morpho-histochemical changes in the gills of turbot, Scophthalmus maximus L., induced by sodium dodecyl sulfate. Ecotoxicology and Environmental Safety, 51: 223-228.

Schwaiger, J., R. Wanke, S. Adam, M. Pawert, W. Honnen \& R. Triebskorn. 1997. The use of histopatological indicators to evaluate contaminant-related stress in fish. Journal of Aquatic Ecossystem, Stress and Recovery, 6:75-86.

Da Silva, M. E. F., J .A. Silva, S. Marangoni, J. C. Novello \& N. C. Meirelles. 2004. A new method to purify hepatic CYP1A of Prochilodus scrofa, a Brazilian freshwater fish. Comparative Biochemistry and Physiology (C), 138: 67-74.

Stien, X., P. Percic, M. Barelli-Gnassia, M. Romeo \& M. Lafaurie. 1998. Evaluation of biomarkers in caged fishes and mussels to assess the quality of waters in a bay of NW Mediterranean Sea. Environmental Pollution, 99: 339-345.

Takashima, F. \& T. Hibya. 1995. An atlas of fish histology: normal and pathological features, 2nd ed. Tokyo, Kodansha.

Teh, S. J., S. M. Adams \& D. E. Hinton. 1997. Histopathological biomarkers in feral freshwater fish populations exposed to different types of contaminant stress. Aquatic Toxicology, 37: 51-70.

Temmink, J., P. Bowmieister, P. Jong \& J. Van der Berg. 1983. An ultrastructural study of chromate-induced hyperplasia in the gill of rainbow trout, Salmo gairdneri. Aquatic Toxicology, 4: 165-179.

Thophon, S., M. Kruatrachue, E. S. Upathan, P. Pokethitiyook, S. Sahaphong, S. Jarikhuan. 2003. Histopathological alterations of white seabass, Lates calcarifer in acute and subchronic cadmium exposure. Environmental Pollution, 121: 307-320.

Van der Oost, R., J. Beber \& N. P. E. Vermeulen. 2003. Fish bioaccumulation and biomarkers in environmental risk assessment: a review. Environmental Toxicology and Pharmacology, 13: 57-149.

Veiga, M. L., E. L. Rodrigues, F. J. Pacheco \& M. J. T. RanzaniPaiva. 2002. Histopathologic changes in the kidney tissue of Prochilodus lineatus, 1836 (Characiformes, Prochilodontidae) induced by sublethal concentration of Trichlorfon exposure. Brazilian Archives of Biology and Technology, 45: 171-175.

Wester, P. W. \& J. H. Canton. 1991. The usefulness of histopathology in aquatic toxicity studies. Comparative Biochemistry and Physiology (C), 100: 115-117.

Wilhelm Filho, D., M. A. Torres, T. B. Tribess, R. C. Pedrosa \& C. H. L. Soares. 2001. Influence of season and pollution on the antioxidant defenses of the cichlid fish acará (Geophagus brasiliensis). Brazilian Journal of Medical Biology and Research, 34: 719-726.

Winkaler, E. U., A. G. Silva, H. C. Galindo \& C. B. R. Martinez. 2001. Biomarcadores histológicos e fisiológicos para o monitoramento da saúde de peixes de ribeirões de Londrina, Estado do Paraná. Acta Scientiarum, 23: 507-514.

Yabe, M. J. S. \& E. O. Oliveira. 1998. Metais pesados em águas superficiais como estratégia de caracterização de bacias hidrográficas. Química Nova, 21: 551-556.

Submitted July 2006 Accepted September 2007 